\title{
Sistem Pejadwalan Kuliah Meggunakan Metode Algoritma Genetika pada Program Magister Fakultas Ekonomi dan Bisnis
}

\author{
Yusuf Afandi ${ }^{1)}$, Wiji Setiyaningsih ${ }^{2)}$ \\ 1, 2) Program Studi Sistem Informasi, Universitas Kanjuruhan Malang, Indonesia \\ Email Penulis: yusufafandiarles@,gmail.com ${ }^{1)}$, wiji@,unikama.ac.id ${ }^{2)}$
}

\begin{abstract}
As per the increase in students of the Masters Program, they will also increase the number of hours / lecture schedule. Willingness and readiness for lecturers make it difficult to determine the appropriate lecture schedule. In addition, the difficulty of making the lecture schedule is because there is still no automated system that can specifically schedule lectures. Limitations of available classrooms allow clash of schedules between classes and the complexity of scheduling courses is also experienced when 1 (one) course can be managed by 3 (three) lecturers (lecturer team). This causes a large number of errors in the scheduling process which results in collisions and delays in scheduling so that the learning and teaching process will be hampered if the scheduling process is still manual. This is important for an implementation to help the scheduling process in order to optimize collisions or collision schedules in the lecture process that occurs in the faculty. The results showed 93\% of respondents from the aspects of the system, user aspects, and interaction aspects of designing and implementing a lecture scheduling system using genetic algorithms stated that it was very helpful and easy to apply as a tool to assist the process of optimizing lecture scheduling to minimize schedule clashes in lectures in the Masters Program.
\end{abstract}

Keywords - Lecture Scheduling, Faculty of Economics and Business, Genetic Algorithms

\begin{abstract}
Abstrak. Sesuai bertambahnya mahasiswa Program Magister juga akan menambah jumlah jam/jadwal perkuliahan. Kesediaan dan kesiapan waktu dosen membuat sulit dalam penentuan jadwal kuliah yang sesuai. Selain itu, kesulitan membuat jadwal kuliah tersebut dikarenakan masih belum adanya sistem yang terotomatis bisa melakukan penjadwalan kuliah secara khusus. Keterbatasan ruang kelas yang tersedia memungkinkan terjadinya benturan jadwal antar kelas dan rumitnya penjadwalan mata kuliah juga dialami ketika 1 (satu) mata kuliah bisa di ampu oleh 3 (tiga) dosen pengajar (tim dosen). Hal ini menyebabkan besarnya angka kekeliruan dalam proses penjadwalan yang mengakibatkan terjadinya benturan dan keterlambatan penjadwalan sehingga proses belajar dan mengajar akan terhambat jika proses penjadwalan masih dengan cara manual. Hal ini penting dilakukan sebuah implementasi untuk membantu proses penjadwalan guna mengoptimalkan benturan atau tabrakan jadwal pada proses perkuliahan yang terjadi di fakultas. Hasil penelitian menunjukkan 93\% responden dari aspek system, aspek pengguna, dan aspek interaksi perancangan serta implementasi sistem penjadwalan kuliah menggunakan algoritma genetika menyatakan sangat membantu dan mudah diaplikasikan sebagai alat dalam membantu proses optimasi penjadwalan kuliah guna memimalisir benturan jadwal pada perkuliahan di Program Magister.
\end{abstract}

Kata Kunci - Penjadwalan Kuliah, Fakultas Ekonomi dan Bisnis, Algoritma Genetika

\section{A. Latar Belakang}

\section{Pendahuluan}

Penjadwalan kuliah merupakan kegiatan yang sangat penting dalam penyelenggaraan proses belajar mengajar yang baik di perguruan tinggi. Penjadwalan kuliah akan menjadi masalah yang besar apabila dalam prosesnya masih belum tersistem. Hal ini akan cukup melelahkan dan memakan waktu dalam proses penjadwalan. Masalah tersebut dialami oleh Fakultas Ekonomi dan Bisnis (FEB). Dari perolehan penghargaan akreditasi internasional Program Magister, FEB UB terus mengembangkan Proses Belajar Mengajar (PMB) di Program Magister FEB. Pertambahan jumlah mahasiswa pada Program Magister FEB secara otomatis akan menambah jumlah jam/jadwal perkuliahan. Kesediaan dan kesiapan waktu dosen membuat sulit dalam penentuan jadwal kuliah yang sesuai. Selain itu, kesulitan membuat jadwal kuliah tersebut dikarenakan masih belum adanya sistem yang terotomatis bisa melakukan penjadwalan kuliah secara khusus. Keterbatasan ruang kelas yang tersedia memungkinkan terjadinya benturan jadwal antar kelas dan rumitnya penjadwalan mata kuliah juga dialami ketika 1 (satu) mata kuliah bisa di ampu oleh 3 (tiga) dosen pengajar (tim dosen). Hal ini menyebabkan besarnya angka kekeliruan dalam proses penjadwalan yang mengakibatkan terjadinya benturan dan keterlambatan penjadwalan sehingga proses belajar dan mengajar akan terhambat jika proses penjadwalan masih dengan cara manual.

\section{B. Batasan Masalah}

1. Sistem penjadwalan mata kuliah ini dibangun untuk menghindari benturan jadwal mata kuliah di Program Magister FEB dalam pembagian dosen mengajar pada jam tertentu dengan variabel: Dosen, Mata kuliah, Kelas, Ruang, Hari, dan Jam.

2. Tim dosen dalam program akan ditampilkan dalam bentuk 1 (satu) dosen dimana dosen tersebut adalah dosen koordinator bagi tim dosen yang telah dibentuk.

3. Pembuatan aplikasi penjadwalan kuliah ini sesuai dengan ketentuan atau aturan yang ada di Program Magister FEB.

4. Dalam pembuatan program ini penulis menggunakan web dan bahasa Pemrograman Hypertext Prepocessor (PHP). 


\section{Tujuan Penelitian}

Adapun tujuan yang akan dicapai dari penelitian ini adalah membangun Sistem Penjadwalan Kuliah untuk mengefektifkan penyusunan jadwal sesuai kesediaan dosen dan meminimalisir adanya benturan jadwal pada Program Magister FEB.

\section{Referensi Artikel Penelitian}

Dalam penelitian, penulis merujuk pada 3 jurnal. Berikut merupakan jurnal rujukan dalam pembangunan system penjadwalan kuliah menggunakan Metode Algoritma Genetika pada Program Magister FEB UB:

1. Terdapat metode penyelesaian penjadwalan kuliah menghasilkan minimalnya angka kesalahan dan efisiensi waktu dalam pembuatan jadwal kuliah dengan meggunakan Algoritma Genetika [1].

2. Penerapan algoritma genetika yang digunakan pada penyusunan jadwal mata kuliah khususnya di STMIK PPKIA belum dapat dikatakan optimal. Dikarenakan dari beberapa uji coba yang dilakukan, dari 100 kromosom yang dibangkitkan hanya mendapat 35 solusi yang optimal dengan permutaion rate sebesar 0,75 , mutation sebesar 0.40 dan jumah generasi 10000. Diperlukan sebuah kombinasi permutation rate, mutation rate dan jumlah generasi yang pas untuk mendapatkan hasil yang optimal. Selain itu juga diperlukan kombinasi dengan metode optimasi lainnya seperti tabu search untuk mendapatkan hasil yang lebih optimal dari penelitian yang ada [2].

3. Dalam mengoptimalkan penyusunan jadwal praktikum diperlukan empat parameter antara lain jumlah populasi, jumlah generasi, crossover dan mutasi. Besar kecilnya masing-masing parameter sangat mempengaruhi jadwal perkuliahan yang dihasilkan. Semakin besar nilai parameternya maka semakin baik pula nilai fitness yang dihasilkan atau jadwal perkuliahan yang dihasilkan semakin optimal [3].

\section{A. Model Pengembangan Waterfall}

\section{METODE}

Metode penelitian yang digunakan dalam penelitian ini adalah penelitian dan pengembangan (research and development). Pembangunan Sistem Penjadwalan Kuliah pada Program Magister FEB dengan metode Algoritma Genetika menggunakan model pengembangan perangkat lunak waterfall [4]. Terdapat lima langkah dalam model pengembangan perangkat lunak waterfall yang digambarkan seperti gambar 1:

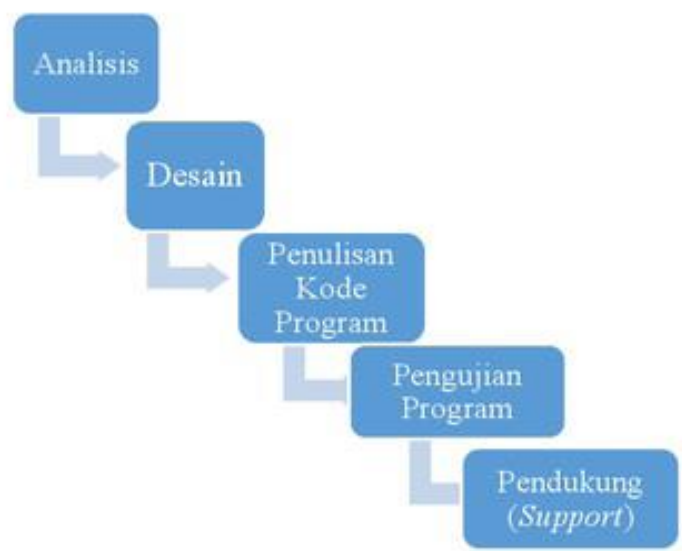

Gambar 1 Model Pengembangan Waterfall

\section{B. Jenis Data}

Jenis data yang diolah pada pembangunan aplikasi untuk Sistem Penjadwalan Kuliah pada Program Magister FEBdengan metode Algoritma Genetika ini berupa hasil wawancara yang diambil dari tenaga kependidikan bagian pengajaran Universitas Brawijaya Malang.

\section{Instrumen Pengumpulan Data}

Instrumen yang digunakan dalam Pembangunan Sistem Penjadwalan Kuliah dengan metode Algoritma Genetika adalah dengan wawancara kepada para nara sumber antara lain:

1. Ketua Program Studi

2. Tenaga kependidikan bagian pengajaran.

\section{Teknik Analisa Data}

Algoritma genetika adalah teknik pencarian algoritma genetika diadopsi dari proses evolusi alam dengan proses seleksi makhluk hidup dalam sebuah populasi”. Dalam implementasinya, algoritma genetika meniru beberapa proses yang terdapat pada evolusi alam dimana evolusi terjadi pada kromosom yang mengkodekan struktur makhluk 
hidup. Individu-individu yang ada pada saat tertentu dalam suatu populasi merupakan individu-individu yang berhasil mempertahankan hidupnya sedangkan yang lemah akan punah. Individu-individu yang berhasil mempertahankan hidupnya akan membentuk individu baru [5].Algoritma genetika dapat dijadikan solusi dalam membangun sistem ini.

Beberapa teori dasar evolusi yang diadopsi oleh algoritma genetika adalah:

a. Evolusi adalah proses seleksi alam dan reproduksi yang bekerja pada kromosom.

b. Seleksi alamiah berhubungan dengan kinerja dari struktur yang dikodekan oleh kromosom.

c. Proses reproduksi adalah titik dimana terjadi evolusi. Rekombinasi akan menciptakan kromosom baru yang berbeda dengan induknya, demikian pula dengan mutasi.

\section{Struktur Umum Algoritma Genetika}

Struktur umum algoritma genetika berikut digambarkan dengan psudocode Bila $\mathrm{P}(\mathrm{t})$ dan $\mathrm{C}(\mathrm{t})$ adalah induk dan keturunan pada generasi t, struktur umum algoritma genetika adalah sebagai berikut:

prosedur algoritma genetika:

begin $\mathrm{t} \leftarrow 0$; inisialisasi $\mathrm{P}(\mathrm{t})$; evaluasi $\mathrm{P}(\mathrm{t})$; while(kondisi terminasi tidak terpenuhi) do rekombinasi $\mathrm{P}(\mathrm{t})$ untuk menghasilkan anak $\mathrm{C}(\mathrm{t})$; evaluasi $\mathrm{C}(\mathrm{t})$;

end seleksi $\mathrm{P}(\mathrm{t}+1)$ dari $\mathrm{P}(\mathrm{t})$ dan $\mathrm{C}(\mathrm{t}) ; \mathrm{t} \leftarrow \mathrm{t}+1$; end

Keterangan: $\mathrm{P}(\mathrm{t})=$ Variabel dan $\mathrm{C}(\mathrm{t})=$ Hasil

Metode pada Algoritma Genetika memiliki beberapa tahap dan sekian perulangan. Dalam kasus ini, metode pada pembuatan jadwal kuliah memiliki beberapa tahap seperti pada gambar 5 yaitu:

1. Populasi

Pembetukan populasi terbaik ditentukan oleh seberapa banyaknya populasi yang dibangkitkan untuk diproses menjadi jadwal. Bentukan populasi dalam penjadwalan kuliah ini adalah banyaknya kromosom dengan masing-masing kromoson mempunyai nilai acak dan tidak ada nilai kromosom yang sama. Semakin banyak populasi yang dibangkitkan, maka semakin sempurna kromosom-kromosom yang akan terpilih dengan nilai yang terbaik

2. Kromosom

Bentukan kromosom adalah dari berapa banyaknya jadwal yang akan di proses penjadwalan dalam sistem. Contoh ketika kita menginputkan 11 jadwal yang akan diproses penjadwalan maka 11 jadwal itu menjadi 11 kromosom dan 11 jadwal itu adalah 1 populasi.

3. Gen $=$ Pertemuan Iterasi

Dalam bentukan gen pada sistem ini ditentukan oleh kriteria yang mungkin masuk dalam sistem ini. Kriteria tersebut adalah hari, jam, ruang, dosen, mata kuliah, kelas. Kriteria-kriteria tersebut dikonversi/penyandiannya menjadi bilangan array dengan nilai masing-masing berbeda. Proses generate algoritma genetikanya menggunakan 3 kriteria saja yang dimasukkan untuk dipakai karena menggunakan Analisa permasalahan hard constraint yaitu hari, jam, dan ruang. Kriteria, dosen, mata kuliah, dan kelas hanya direlasikan saja sesuai dengan hasil generate algoritma genetikanya.

4. Crossover

Crossover rate berfungsi mengatur prosentase kromosom yang akan dipindah silang (rentang 0-100). Dalam kasus penjadwalan ini akan digunakan model One-Point Crossover. Dengan penjelasan sebagai berikut. Contoh kerja operator ini adalah dengan menentukan crossover point (gen tertentu). Kromosom baru pertama berisi gen pertama sampai gen crossover point dari kromosom induk pertama ditambah dengan gen dari crossover point sampai gen terakhir dari kromosom induk kedua. Kromosom baru kedua berisi gen pertama sampai gen crossover point dari induk kedua ditambahkan dengan gen dari crossover point sampai gen dari kromosom induk pertama. Adapun metode crossover ini dapat diilustrasikan dibawah.

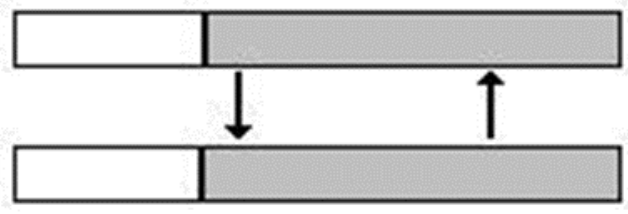

Dari ilustrasi di atas maka contoh penerapan metode One-Point Crossover adalah sebagai berikut:

Parent 1: $12345 \mid 6789$

Parent 2: $45368 \mid 9721$

Setelah proses crossover turunan yang dapat dihasilkan adalah dari kedua parent diatas adalah: 
Parent 1: $12345 \mid 9721$

Parent 2: $45368 \mid 6789$

5. Mutasi

Mutasi rate disini berfungsi mengatur prosentase gen yang akan diganti (mutasi). Setiap hasil akhir pada mutasi tidak berbatas nilainya, semakin banyak hasil mutasi berdasarkan jumlah kromosom yang dibangkitkan dan maksimal generasi maka semakin besar pula potensi tidak adanya bentrokan jadwal pada sistem penjadwalan kuliah ini. Berikut adalah simulasi dari setiap tahapan algoritma genetika.

\section{Hasil dan Pembahasan}

\section{A. Contex Diagram Pembangunan Sistem Penjadwalan Kuliah}

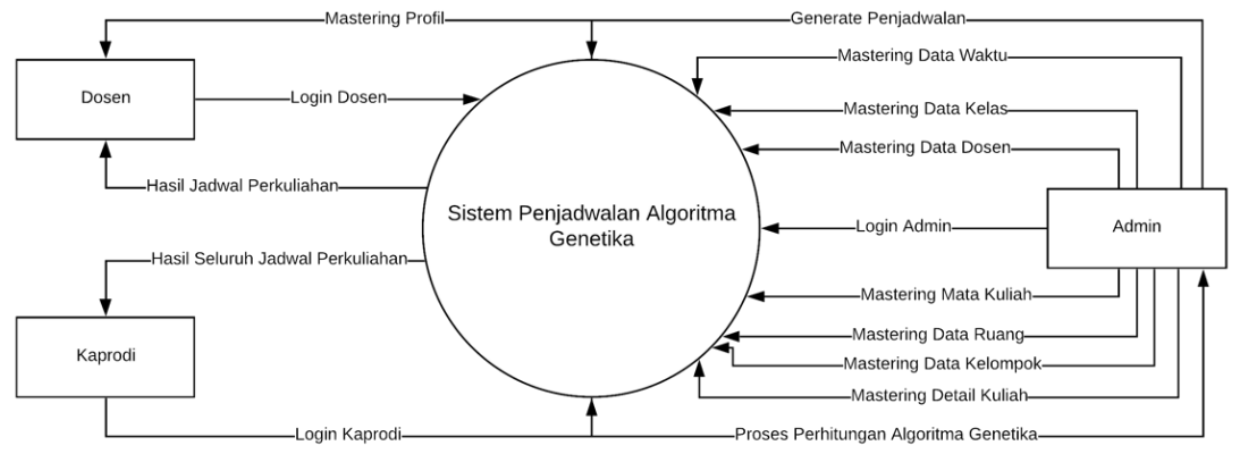

Gambar 1. Contex Diagram

Dalam gambar diatas dijelaskan bahwa pada Sistem Penjadwalan Algoritma dibagi menjadi dua user yaitu admin dan dosen. Dalam menu dosen hanya terdapat tiga fitur 1) Login User, 2) Mastering Profil, dan 3) Hasil Jadwal Perkuliahan. Sedangkan dalam menu admin terdapat sembilan firut yaitu 1) Login User, 2) Mastering Data Waktu, 3) Mastering Data Kelas, 4) Mastering Data Dosen, 5) Mastering Data Kuliah, 6) Mastering Data Ruang, 7) Mastering Data Kuliah, 8) Generate Penjadwalan, dan 9) Halaman Proses Perhitungan Algoritma Genetika.

\section{DFD Level 1 Pembangunan Sistem Penjadwalan Kuliah}

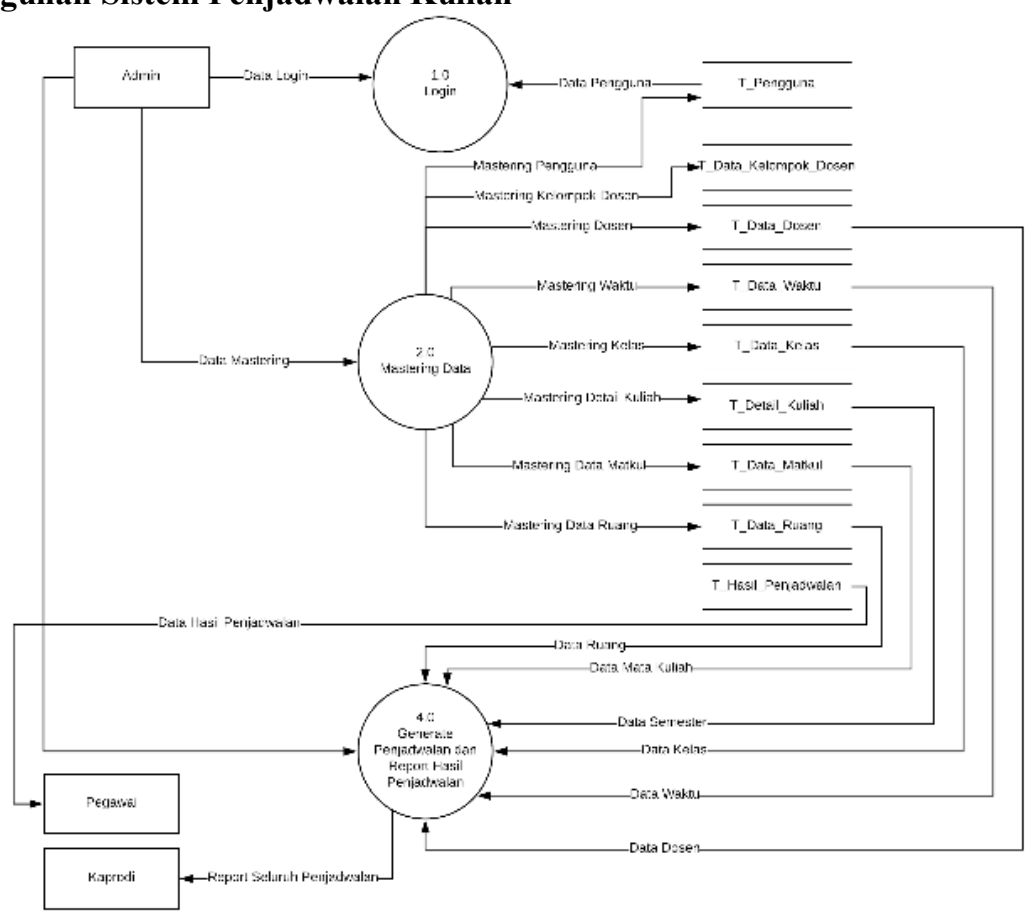

Gambar 2 DFD Level 1

Dalam gambar diatas dijelaskan secara detail proses login user, mastering data, generate penjadwalan dan report hasil penjadwalan beserta user yang akan mengakses system penjadwalan tersebut. Pada point 1.0 dijelaskan bahwa user yang sudah terdaftar kedalam database T_Pengguna lah yang bisa masuk kedalam system. Pada point 2.0 
dijelaskan bahwa hanya admin yang dapat memastering seluruh data mastering, fitur tersebut dapat merubah, menambah, dan menghapus seluruh data mastering. Pada point 3.0 dijelaskan bahwa proses Generate jadwal akan ditampilkan didalam halaman tersebut. Fitur generate jadwal hanya bisa di akses oleh admin namun tidak bisa dirubah, ditambah dan dihapus. Pada point terakhir 4.0 adalah berisi halaman laporan hasil yang sudah berhasil di generate oleh system menggunakan Algorima Genetika.

\section{Flowchat Sistem Mastering Data}

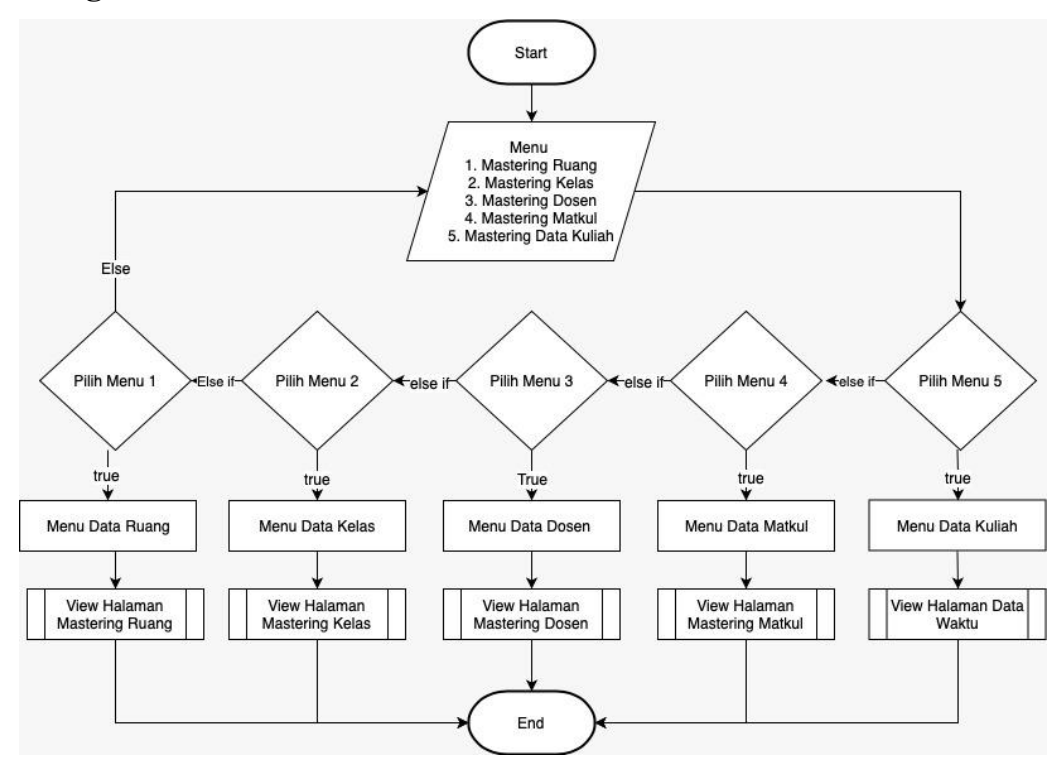

Gambar 3. Flowchart Mastering Sistem Penjadwalan Kuliah

Menjelaskan didalam halaman mastering terdapat lima menu yaitu 1) Menu Data dosen berisikan seluruh data dosen, Admin juga dapat menambah, mengedit, dan menghapus data dosen. 2) Menu Jenis Mata kuliah berisikan seluruh data jenis mata kuliah yang terdapat di FEB. Admin dapat menambah, mengedit, dan menghapus data jenis mata kuliah tersebut. 3) Menu Ruang berisikan Ruang yang terdapat di FEB. Admin dapat menambah, mengedit, dan menghapus data Ruang tersebut. 4) Menu adalah penggabungan dari ke empat menu yaitu semester, jenis mata kuliah, Ruang, dan data dosen yang akan jadikan menjadi satu guna menspesifikan dosen tersebut dengan jenis mata kuliahnya dan menjadi menu Data Kuliah. Admin dapat menambah, mengedit, dan menghapus data waktu tersebut.

\section{Flowchart Gererate Sistem Penjadwalan}

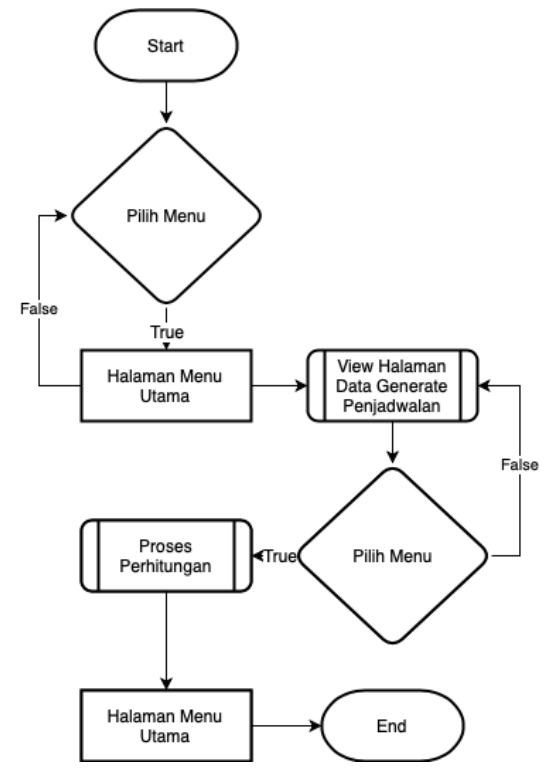

Gambar 4. Flowchart Proses Gererate Algroritma Genetika

Pada menu generate jadwal berisikan proses perhitungan algoritma genetika untuk menentukan seleksi penjadwalan terhadap dosen yang sudah di mastering oleh admin. Sistem akan menampilkan detail perhitungan yang terdapat di 
algoritma genetika sehingga menampilkan hasil penjadwalan dosen.

\section{Desain ERD Sistem Penjadwalan Kuliah}

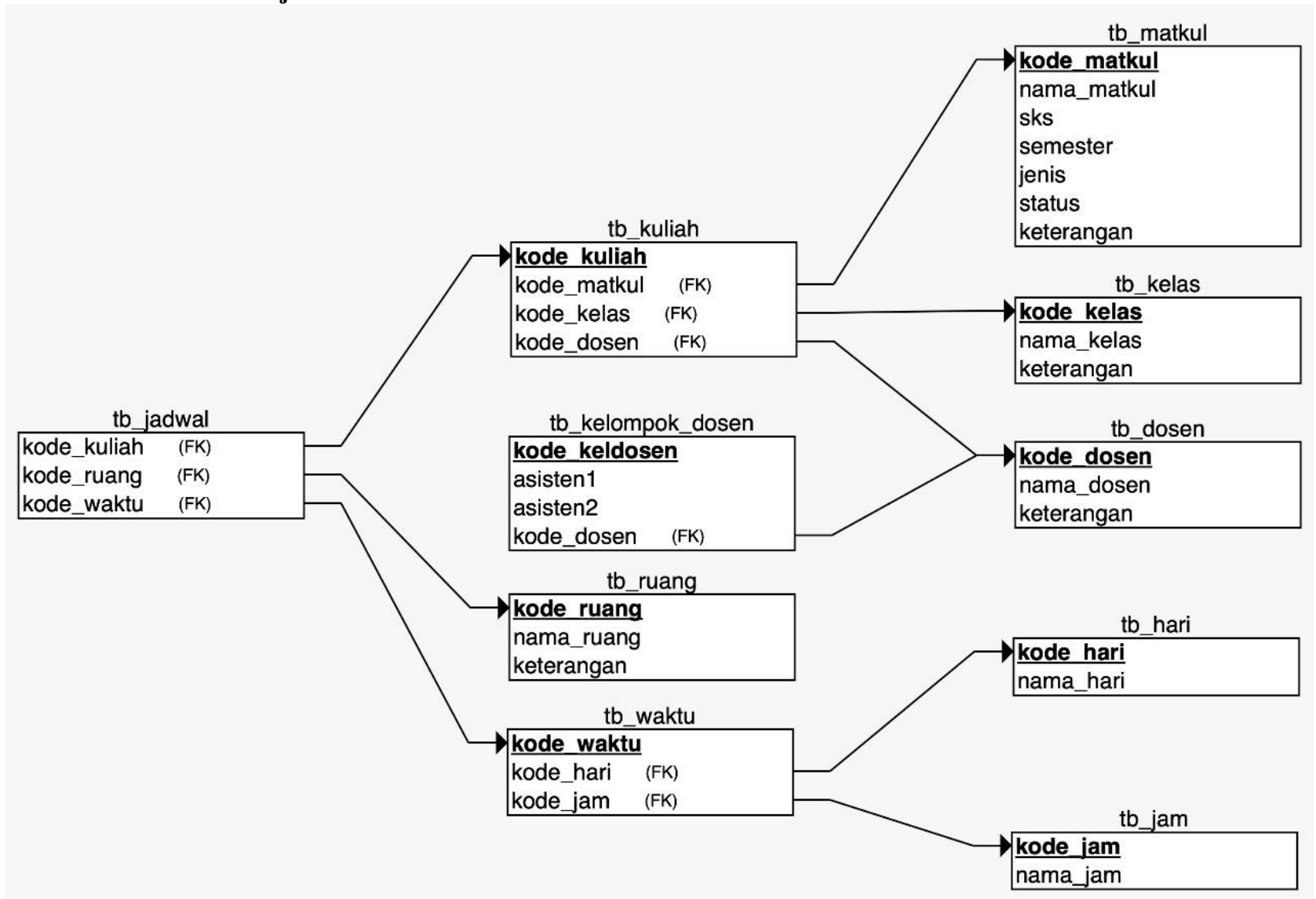

\section{Gambar 5. ERD Sistem Penjadwalan Kuliah}

Berikut ini adalah penjelasan mengenai struktur basis data pada sistem penjadwalan kuliah pada Program Magister FEB:

Tabel Master Dosen

Tabel Dosen untuk menyimpan data dosen yang berfungsi sebagai pendataan data dosen yang terlibat dalam proses penjadwalan dosen.

Tabel Master Kelompok Dosen

Tabel kelompok dosen untuk menyimpan data kelompok dosen yang sudah direlasikan dengan data dosen untuk menentukan dosen koordinator dan asisten dosennya.

Tabel Master Ruang

Tabel Ruang untuk menyimpan seluruh data Ruang yang berfungsi sebagai manajemen data Ruang

Tabel Master Detail Kuliah

Tabel Detail Kuliah untuk menyimpan data kuliah yang sudah direlasikan dengan data jenis mata kuliah sebagai manajemen data mata kuliah dengan dosen atau kelompok dosen dan semester disebut sebagai tabel detail pada database.

Tabel Master Waktu

Tabel Waktu untuk menyimpan data waktu yang sudah direlasikan dengan data jam dan hari sebagai manajemen data waktu dengan jam dan hari yang disebut sebagai tabel detail pada database.

Tabel Master Hari

Tabel Hari untuk menyimpan seluruh data hari yang berfungsi sebagai manajemen data hari.

Tabel Master Jam

Tabel Jam untuk menyimpan seluruh data hari yang berfungsi sebagai manajemen data jam

Tabel Master Matakuliah

Tabel Jenis Mata Kuliah untuk menyimpan seluruh data jenis mata kuliah yang berfungsi sebagai manajemen data jenis mata kuliah.

Tabel Master Jadwal 
Tabel Jadwal untuk menyimpan data jadwal yang sudah direlasikan dengan data mata kuliah dan waktu sebagai hasil dari data jadwal.

Tabel Master Admin

Tabel Master Admin untuk menyimpan data user dan password pengguna.

\section{Implementasi Proses Generate Sistem Penjadwalan Kuliah}

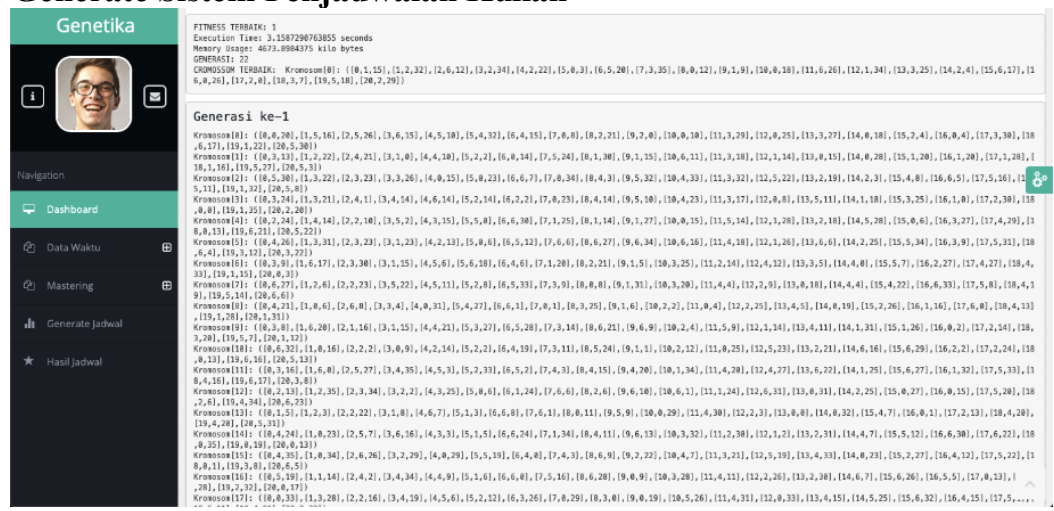

Gambar 6. Proses Penjadwalan Algoritma Genetika

Halaman proses generate penjadwalan berisi tampilan proses beserta perhitungan metode algoritma genetika untuk mengenerate seluruh kriteria guna mendapatkan hasil penjadwalan dengan ketentuan tidak lagi adanya bentrokan jadwal yang terdapat pada proses penjadwalan. Halaman ini hanya bisa diakses oleh admin.

\section{Implementasi Hasil Penjadwalan Kuliah}

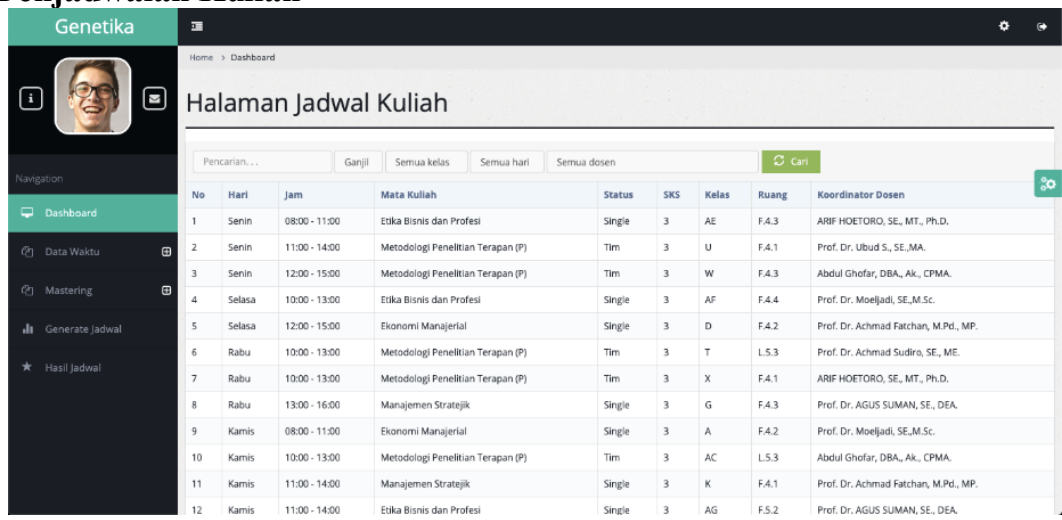

Gambar 7. Hasil Penjadwalan Algoritma Genetika

Halaman hasil penjadwalan berisi mastering hasil penjadwalan dari proses generate algoritma gen etika. Pada halaman ini dapat dilihat bahwa sudah terbentuk jadwal yang fix untuk para pengajar dan sudah dapat dipastikan bahwa tidak ada jadwal yang bentrok pada penjadwalan kuliah tersebut. Admin saja yang bisa mengakses halaman ini dan memiliki fitur pencarian berdasarkan kebutuhan yang akan dipilih.

\section{KESIMPULAN}

1. Dalam penulisan skripsi ini telah dilakukan pembangunan optimalisasi sistem penjadwalan kuliah menggunakan algoritma Genetika di Program Magister FEB. Berdasarkan hasil observasi sebelumnya, FEB melakukan penjadwalan secara manual dengan menggunakan MS. Excel. Hal tersebut dirasa kurang optimal dan setelah adanya sistem, berdasarkan responden dan implementasi program aplikasi, dapat diambil kesimpulan bahwa rata- rata total 93\% responden dari aspek system, aspek pengguna, dan aspek interaksi perancangan serta implementasi sistem penjadwalan kuliah menggunakan algoritma genetika menyatakan sangat membantu dan mudah diaplikasikan sebagai alat dalam membantu proses optimasi penjadwalan kuliah guna memimalisir benturan jadwal pada perkuliahan di Program Magister FEB.

\section{UCAPAN TERIMA KASIH}

Dalam menyusun skripsi ini, peneliti mendapat bimbingan, dorongan, semangat, dan bantuan dari berbagai pihak, oleh karena itu perkenankanlah pada kesempatan ini peneliti mengucapkan terima kasih kepada:

1. Bapak Dr. Pieter Sahertian, M.Si selaku Rektor Universitas Kanjuruhan Malang

2. Bapak Dr. I Ketut Suastika, M.Si selaku Dekan Fakultas Sains dan Teknologi Universitas Kanjuruhan Malang 
3. Bapak Yoyok Seby Dwanoko, M.Kom., selaku Kaprodi Sistem Informasi

4. Ibu Wiji Setiyaningsih, M.Kom selaku dosen pembimbing yang telah meluangkan waktu dan tenaganya, serta penuh kesabaran memberikan nasihat dan saran-saran yang berharga secara bijak untuk membimbing peneliti dalam penyelesaian penelitian ini.

5. Orangtua yang tiada henti mengikhlaskan perhatian, kasih sayang dan pengorbanannya, semoga Allah selalu mengabulkan doa dan memberi keselamatan kepada kalian. Amin

6. Keluarga, terutama istri dan anak, dan mertua yang selalu mendukung agar selesai skripsi dan lulus kuliah

7. Teman-teman, khususnya anak sistem informasi angkatan 2012 yang telah membantu selesainya skripsi ini

8. Serta pihak-pihak yang tidak dapat peneliti sebutkan satu persatu, namun tidak mengurangi rasa hormat saya kepada kalian

\section{REFERENSI}

[1] M. C. U. \&. Y. S. Andrie Tri Laksono, "Sistem Penjadwalan Kuliah Menggunakan Metode Algoritma Genetika (Studi Kasus: Fakultas Kedokteran dan Kesehatan Universitas Muhammadiyah Jakarta)," Studia Informatika: Jurnal Sistem Informasi, vol. 9, pp. 177-188, 2016.

[2] A. I. M. H. \&. S. Lusiana Paranduk, "Sistem Informasi Penjadwalan Mata Kuliah Menggunakan Algortima Genetika Berbasis Web," in Seminar Nasional Aplikasi Teknologi Informasi (SNATi) 2018, Yogyakarta, 2018.

[3] A. I. \&. C. S. Agil Assagaf, "Membangun Sistem Informasi Penjadwalan Dengan Metode Algoritma Genetika Pada Laboratorium Teknik Informatika Unversitas Muhammadiyah Maluku Utara," Junal Ilmiah ILKOMINFO - Jurnal Ilmu Komputer dan Informatika, vol. Vol 1 No. 2, pp. 95-105, 2018.

[4] M. S. Rosa Ariani Sukamto, Rekayasa Perangkat Lunak Struktur dan Berorientasi Objek, Bandung: Informatika, 2014.

[5] R. C. Mitsuo Gen, Genetic Algorithms \& Engineering Optimization, USA: John Wiley \& Sons, Inc, 2010. 